\title{
Jubilantka Jana Pleskalová
}

Počátkem letošního roku oslavila významné životní jubileum brněnská lingvistka, profesorka Jana Pleskalová. Celý její život a profesní dráha jsou spjaty s Brnem, kde se narodila 1. února 1949 jako Jana Kýrová. O osmnáct let později, v roce 1967, zahájila studium oborů čeština a latina na zdejší univerzitě, tehdy Jana Evangelisty Purkyně. K jejím učitelům, kteří výraznou měrou ovlivnili její pozdější vědeckou dráhu, patřily takové osobnosti jako Arnošt Lamprecht, Antonín Bartoněk, Radoslav Večerka, Dušan Šlosar nebo Jana Nechutová. Počátkem sedmdesátých let minulého století se etablovala jako samostatná lingvistická subdisciplína onomastika, tedy nauka o vlastních jménech, a právě pro tento obor získal Janu Pleskalovou přední český onomastik Rudolf Šrámek, působící v brněnské pobočce Ústavu pro jazyk český ČSAV, který na filozofické fakultě vedl onomastické semináře. Právě pod jeho vedením, byt formálně byl vedoucím práce Jan Chloupek, vznikla v roce 1972 diplomová práce Jany Pleskalové Pomístní jména na Ivančicku, jíž úspěšně zakončila své studium. O rok později získala na stejné fakultě titul PhDr. v oboru český jazyk, a to na základě práce Mikrotoponymie na Ivančicku (př́spěvek ke studiu pomístních jmen na Moravě s bibliografií moravské mikrotoponomastiky v letech 1918-1970).

V následujícím roce nastoupila Jana Pleskalová do dialektologického oddělení Ústavu pro jazyk český ČSAV a začala se pod vedením Jana Balhara podílet na výzkumu a zpracovávání nářečního materiálu pro Český jazykový atlas. Vedle bádání dialektologického pokračovala i její spolupráce s Rudolfem Šrámkem na výzkumu pomístních jmen a do oblasti onomastiky se postupně přeneslo těžiště její badatelské činnosti. Výzkumná práce v oblasti anoikonym byla završena obhájením kandidátské disertace s názvem Tvoření pomístních jmen na Moravě a ve Slezsku v roce 1989 (knižně vyšla v roce 1992).

Ani během působení v Akademii věd neztratila Jana Pleskalová kontakt s univerzitním prostředím. Od roku 1984 se jako lektorka češtiny podílela na Letní škole slovanských studií organizované filozofickou fakultou, od následujícího roku pak externě přednášela také na fakultě pedagogické. V roce 1993 se pak Ústav českého jazyka Filozofické fakulty již opět Masarykovy univerzity stal jejím hlavním působištěm. Zaměřila se zde zejména na historickou gramatiku a vývoj češtiny, stranou jejího zájmu však nezůstávala ani onomastika, a to jak v oblasti výzkumu, tak výuky. Kurzy věnované historické toponomastice a vlastním jménům osobním patřily a stále patří k velice oblíbeným a hojně navštěvovaným. Po svém učiteli Dušanu Šlosarovi převzala Jana Pleskalová nejen výuku historické gramatiky a vývoje spisovné češtiny pro bohemisty, ale také výuku staré češtiny pro studenty historických 
oborů. Zejména pro ně je určeno doplněné a přepracované Šlosarovo skriptum Stará čeština pro nefilology (2001, 2. vyd. 2003). Těžištěm odborné činnosti Jany Pleskalové se v této době stala především antroponyma; jim je věnována habilitační práce z roku 1996 Tvoření nejstarších českých antroponym (v roce 1998 vydaná knižně s názvem Tvoření nejstarších českých osobních jmen). Jmenování profesorkou českého jazyka následovalo o sedm let později (2003).

Už v roce 1999 se Jana Pleskalová stala vedoucí Ústavu českého jazyka Filozofické fakulty Masarykovy univerzity a v jeho čele stála plných patnáct let. Velice rychle se zorientovala ve změnách podmínek pro podporu vědy a výzkumu, které přinesl konec 90 . let a počátek nového tisíciletí. J. Pleskalová se stala řešitelkou a spoluřešitelkou několika mezinárodních projektů - ve spolupráci s Univerzitou Komenského v Bratislavě to byl v letech 2002-2003 projekt Konfrontace principů ve vývoji češtiny a slovenštiny, ve spolupráci s vídeňskou slavistikou projekt J. V. Zlobický - seine Bedeutung als Initiator und Vermittler der böhmischen und slawischen Studien in der Habsburgermonarchie des 18. Jahrhunderts, v jehož rámci se roku 2004 autorsky podílela na kolektivní monografii Vídeňský podíl na počátcích českého národního obrození; J. V. Zlobický (1743-1810) a současníci: život, dílo, korespondence. Mezi lety 2003-2005 byla hlavní řešitelkou grantu Dějiny české jazykovědné bohemistiky, završeného monografí Kapitoly z dějin české jazykovědné bohemistiky (2007), v letech 2005-2011 stála v čele Výzkumného centra vývoje staré a střední češtiny (od praslovanských kořenů po současný stav) a v letech 2007-2011 byla členkou odborného týmu významného celofakultního výzkumného záměru Středisko pro interdisciplinární výzkum starých jazyků a starších fází jazyků moderních. Editorsky i autorsky - množstvím hesel především z oblasti onomastiky a vývoje pravopisu - se podílela na vzniku Encyklopedického slovníku češtiny (2002) a následně i na podstatně rozšířeném a přepracovaném Novém encyklopedickém slovníku češtiny (2016), který je přístupný i online. J. Pleskalová v něm zpracovala hesla jako Antroponymum, Diakritický pravopis, Onomastika, Nabodenícko, Parasystém a dalších více než 70 položek. Několik hesel zpracovala také pro Antropologický slovník (2009), podílela se na zahraničních onomastických encyklopediích Namenforschung - Name Studies - Les noms propres (1996), Stowiańska onomastyka (2003) či Europäische Personennamensysteme (2007). V současné době je členkou řešitelského týmu projektu Kramářské písně $v$ brněnských historických fondech (NAKI II). Je členkou redakční rady onomastického časopisu Acta onomastica, Jazykovědného sdružení ČR, vědecké rady FF MU, oborových komisí pro obory český jazyk a pomocné vědy historické. Na brněnské filozofické fakultě stále přednáší a vede závěrečné práce především $\mathrm{z}$ onomastiky. $\mathrm{K}$ jejím výrazným pedagogickým úspěchům patř́ to, že přivedla šest svých studentek k úspěšnému obhájení onomasticky či diachronně zaměřených doktorských prací.

Svou dlouholetou činorodou aktivitou si bezpochyby vydobyla - slovy staročeského kronikáře - „jmene dobrého“, jež se rozhodně neomezuje jen na oblast onomastiky.

Do dalších let přejeme jubilantce i nadále dostatek inspirativních badatelských otázek a uspokojení z jejich tvůrčího rozpracování a také mnoho životní pohody, optimismu i energie. 


\section{Veronika Bromová}

Department of Czech Language

Faculty of Arts, Masaryk University

Arna Nováka 1, 602 oo Brno

Czech Republic

bromova@phil.muni.cz licence nebo výjimky či omezení přislušných práv. 